\title{
Italian Science Policy Condemned
}

ITALY's economic miracle and the excellence of her nuclear physics are arresting witnesses to how well a country can do without a science policy. This at least is the inference from the latest of the series of reviews of national science policies prepared by the Organisation for European Cooperation and Development (Reviews of National Science Policy-Italy, OECD, Paris, £2). The report, a sharp departure from its generally bland and unprovocative predecessors, finds almost nothing right with Italian science policy-pitiable funds, confused organization, reactionary professors are only some of the failings of which Italy is indicted by her inquisitors.

It is not surprising that the report has taken so long to see the light of day. The original draft, completed some two years ago, was sent to interested parties in Italy in preparation for the usual "confrontation" mecting between the OECD examiners and the authorities of the country concerned. It secms that the asperity of the examiners' strictures made the Italian authorities reluctant to turn up for the meeting; certainly matters were made worse when shortly before the elections last year, copies of the draft report were handed out by dissident research workers conducting a sit-in at the headquarters of the National Research Council (CNR).

It is hard to say how far the draft report has been adulterated in the published version. But apart from the account of the confrontation meeting, which reads as a vapid anticlimax to the drama that preceded it, the review presents an arsenal of ammunition for Italian research workers who ficel themselves hard done by. What the review does not explain is how a patient, who by the doctors' stock criteria should be dead, is in fact enjoying splendid economic health. Could it be that economic performance and scientific and technological progress are less intimately connected than is customarily supposed ?

The two salient features of Italy's research budget are its size and its imbalance. Despite an economic growth rate that has been second only to that of Japan and Canada in recent years, Italy devoted only $0 \cdot 6$ per cent of its GNP to scientific research in 1963 (compared with more than 2 per cent for Britain and Germany) and by 1967 this had climbed only to 0.9 per cent of which less than half was provided from public funds. The aggregate research expenditure in 1967 in fact amounted to some L.375,000 million ( 250 million), but even this small cake was very unevenly divided, one fifth being devoted to the National Council for Nuclear Energy (CNEN) and an equally large slice going towards international agencies, principally Euratom, CERN, ELDO and ESRO.

Granted the budgetary limitations on scientific research, the principal wrath of the OECD inquisitors descends on the way in which science policy is organized at a governmental level. There is, too, the stifling atmosphere which encompasses research at the universities, and which is chiefly to be ascribed to the inordinate power, and seemingly inordinate abuse of it, that is traditionally devolved on Italian professors. Balik basdan kokar, as the Turks say, "A fish rots from the head down", might almost have been the mottoes to these sections of the report, although the inquisitors mince their words more finely. (Indeed, in parts of the report, which read as if they had been dragged rather than translated from the French, it is hard to be certain what message underlies the multiple wrappings of diplomatic verbiage). On the government level, the principal failing is the nebulous division of responsibility between the various organs concerned with the formulation of science policy. Chief of these is the National Research Council (CNR) which is loaded with a multiplicity of functions including both the administration of certain types of research and advising the government on science policy. The president of the CNR submits an annual report to parliament which in effect forms the basis for its research policy. Tho CNR, however, disposes of less than a fifth of the public funds devoted to research.

A slightly larger sum is at the disposal of the CNEN which in practice is a largely autonomous body (hence, perhaps, its excellence), whilst the remainder of the public research funds (excluding those made to international agencies) are administered by the ministry of education and other ministries. Supervising the CNR is the Committee of Ministers for Economic Planning (CIPE), but neither the committee nor the Minister for the Coordination of Scientific and Technical Research is equipped to exert significant influence on the overall planning of scientific and technical research. Indeed, the last minister, whose job seems generally to be regarded as a farce, declared-in joking vein-"More than ten ministers undertake scientific research; I administer none, I just go round poking my big nose into other people's business".

The problems of this structure cited in the OECD) review include the dissatisfaction among scientists with the membership of the CNR, which includes too many professors and too few junior staff; the cumborsome machinery of the CNR and the delay in extracting a grant; and the handicaps on the CNR's operation, notably that the president's report to parliament is merely indicative and not legally binding, and the fact that many of the CNR's resources have to be devoted to shoring up the universities.

The dominant feature of industrial research in Italy which commands more than half the total research funds when the contribution of the state-aided enterprises is included, is the excellence of the research carried out by the largest concerns and the serious neglect or inability to undertake research by almost all the others. This is reflected in the technological balance of payments which has grown from a deficit with the rest of the world of $\$ 11$ million in 1956 to $\$ 113$ million in 1965 . The deficit in 1965 represented more than half of the total industrial research in that year. At present, the examiners say, the government contributes little to industrial research and has no 
effective means of orienting industrial research strategy in the foreseeable future.

In the universities, the dearth of research funds is compounded by a shortage of research personnel at every level and an archaic structure which allows professors to behave as autocrats and offers no secure career to younger scientists. The examiners do not mention the notorious habit of a handful of Italian professors, who sell duplicated copies of their notes to students at exortionate fees, but they do mention the complaints that professors devote too much of their time to private money-making activities and too little to teaching. This abuse has reached such a pitch that a bill is now in preparation to set minimum teaching hours for professors who would be obliged to keep a record of their daily lectures and the reasons for any absence. Major weaknesses in the student side of the educational ladder are that students entering university are taught too much Latin and too little science, and that more than half the students come from upper class families representing less than 10 per cent of the population.

"Italian scientific and technical potential," the OECD examiners conclude, "is not yet sufficient, whether in the light of the place occupied by the Italian economy in the world or in relation to the other industrialized countries of Europe. This insufficiency is manifest both in the number of researchers and, above all, in the facilities available to them for the conduct of their work." As if to lay any dust they may have stirred, the examiners go on to affirm that the necessary reform measures are in hand and that no one is better aware of the problems or the means of tackling them than the Italians themselves. In the discussion of the background report the examiners, who include Professor Harvey Brooks of Harvard University, Professor Guy Ourisson of Strasbourg and Dr Jacques Spaey, secretary-general of the Belgian national council for science policy, remark particularly on the trials faced by young research staff at the universities. Their salaries are too low, both in relation to their colleagues in industry and their professors, and the professors take too much credit for the work done by their subordinates. University grants should be doubled immediately and subsequently trebled to bring them into line with European standards and the hierarchy of

\section{Moon Rocks}

\section{First Resulis Published}

Results of the preliminary analysis by the Lunar Receiving Laboratory of the $22 \mathrm{~kg}$ of material returned from the Moon are reported in this week's Science $(165,1211 ; 1969)$, and the chief conclusion is that the surface at Tranquillity Base is unlike any known terrestrial rock or meteorite. This is chiefly because of comparatively high concentrations of the elements $\mathrm{Ti}$, $\mathrm{Zr}, \mathrm{Y}$ and $\mathrm{Cr}$, and because of low amounts of $\mathrm{Na}, \mathrm{K}$ and $\mathrm{Rb}$. Titanium oxide, for example, makes up roughly 10 per cent by weight of the samples. The university posts should be remoulded, notably by creating a new rank of associate professor. The universities should also be streamlined and more closely integrated into the country's economic and social life. If this is to happen, the examiners declare, it is "particularly desirable that they should not be run solely by academics".

Turning to the non-academic science institutes, the three inquisitors say that administration of the public service institutes, attached haphazardly to various ministries, should be rationalized and simplified. The level of industrial research is manifestly too low but the state has nothing to offer the large firms and has made little progress in assisting the smaller ones. At the government level, much is to be hoped from the reform project to create a Ministry for Scientific and Technical Research. Nonetheless, the present plan "does not seem to establish a sufficiently clearly defined hierarchy of competences and responsibilities but rather to lead to the duplication of influences; in particular, responsibilities for programming and administration are not sufficiently clearly distinguished".

The examiners, whilst expressing their anxiety not to meddle with matters beyond their competence, recommend a discarding of the Italian practice whereby the same body, for instance the CNR, is charged both with doling out funds and setting the guidelines for scientific policy. It is essential, they say, to separate the two functions, and for this reason the Prime Minister should be advised by a Science Policy Council, of which he would be chairman. Members of the council would be drawn from the universities, industry and public life. The council would advise on science budgets and guidelines for the national programme but would not be concerned with the distribution of funds. A Committee for Applied Research should take over from the CNR responsibility for this area of its activities and the CNR should concentrate on the support of fundamental research.

The examiners commend the Italian authorities for their excellent judgment in supporting nuclear re. search under the CNEN at a high level of funding, but they have no words of comfort for Italy's technological gap, which can only increase with time under the present arrangements. staff of the laboratory say that the crystalline rocks are surface lavas or igneous rocks from noar the surface, but refuse to be drawn into a discussion of whether there was a process like terrestrial volcanism, or whether the volcanism could have been triggered by meteorite impacts. There seem to be two alternative ways of explaining the peculiar composition-either the original rock which produced the lava was different from anything found in the mantle of the Earth, or it has undergone different processes.

The report also draws particular attention to the age of the samples determined by $\mathrm{K} / \mathrm{Ar}$ dating, which 